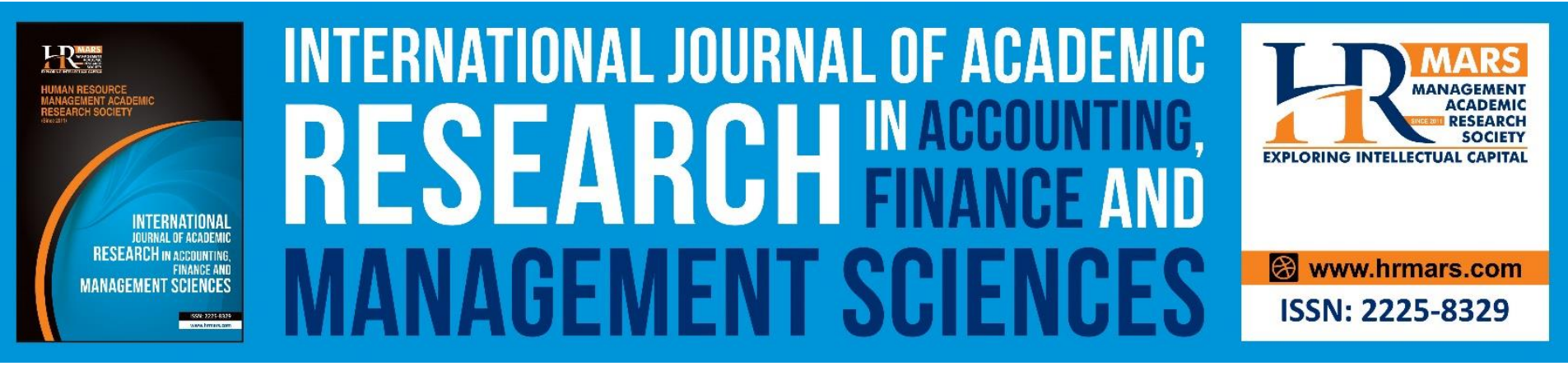

\title{
Carbon Stakeholder Collaboration's Influence on The Carbon Accounting Implementation of Organizations in Malaysia.
}

Nur Fatin Kasbun, Ong Tze San

To Link this Article: http://dx.doi.org/10.6007/IJARAFMS/v11-i1/8289

DOI:10.6007/IJARAFMS /v11-i1/8289

Received: 10 December 2020, Revised: 11 January 2021, Accepted: 29 January 2021

Published Online: 16 February 2021

In-Text Citation: (Kasbun \& San, 2021)

To Cite this Article: Kasbun, N. F., \& San, O. T. (2021). Carbon Stakeholder Collaboration's Influence on The Carbon Accounting Implementation of Organizations in Malaysia. International Journal of Academic Research in Accounting Finance and Management Sciences, 11(1), 20-36.

Copyright: (c) 2021 The Author(s)

Published by Human Resource Management Academic Research Society (www.hrmars.com)

This article is published under the Creative Commons Attribution (CC BY 4.0) license. Anyone may reproduce, distribute, translate and create derivative works of this article (for both commercial and non-commercial purposes), subject to full attribution to the original publication and authors. The full terms of this license may be seen

at: http://creativecommons.org/licences/by/4.0/legalcode

\section{Vol. 11, No. 1, 2021, Pg. 20 - 36}

http://hrmars.com/index.php/pages/detail/IJARAFMS

JOURNAL HOMEPAGE

Full Terms \& Conditions of access and use can be found at http://hrmars.com/index.php/pages/detail/publication-ethics 


\title{
Carbon Stakeholder Collaboration's Influence on The Carbon Accounting Implementation of Organizations in Malaysia.
}

\author{
Nur Fatin Kasbun, Ong Tze San \\ School of Business and Economics, Universiti Putra Malaysia
}

\begin{abstract}
Reduction of corporations' direct or indirect carbon emissions is one of the most important yet complicated challenges facing by the society in the effort for climate change mitigation. It is also empirically proven that the industry and the industrial have been acknowledged as the major causes and contributors to carbon dioxide $\left(\mathrm{CO}_{2}\right)$ emissions. Business corporations contribute to the success of converting natural resources into wealth, which have directly created today's sophisticated social world but unfortunately, at the same time, deteriorating the environment. The economic production forms unfortunately will continue to contribute to pollution. Consequently, in order to achieve sustainability, corporation specifically corporate accounting should not only focus on financial profitability but must take action to counter the effects of their greenhouse gases emissions especially carbon dioxide, the cause of climate change for the betterment of the environment. One of the ways is to collaborate with stakeholders in the effort of carbon emissions mitigation because the hazardous impacts of climate change are not only affecting the environment but also the economy.
\end{abstract}

\section{Introduction}

The influential dynamism of present corporate organizations has led to simultaneous societal and environmental transformation. Conventionally, it is customarily that corporate organizations prioritize revenue and profit opportunities more than anything. However, due to the increased societal awareness of environmental protection and concerns on the impacts of climate change, corporate organizations must balance their profit-making interest and contribution to environmental and societal wellbeing. The environmental degradation caused by carbon emissions affects business operations in every country and region worldwide. As one of the developing nations, Malaysia is considerably responsible for the environment. As the Malaysian economy is promptly thriving as the nation aspires to be a high-income nation, Malaysia continues to be attentive and cautious of the responsibility toward environmental stewardship and sustainability in creating a better life quality for the Malaysian citizens and to decrease climate change negative impacts. Hence, Malaysia is undeniably trying to be active in mitigating $\mathrm{CO}_{2}$ emissions through various domestic mitigation efforts 
INTERNATIONAL JOURNAL OF ACADEMIC RESEARCH IN ACCOUNTING, FINANCE AND MANAGEMENT SCIENCES

Vol. 11, No. 1, 2021, E-ISSN: 2225-8329 ๑ 2021 HRMARS

and intergovernmental instruments such as an international agreement intended at decreasing greenhouse gas (GHGs) atmospheric concentrations (Safaai et al., 2011). The plan to achieve the country's pledges for carbon footprint reduction at the climate change conferences in Paris (Paris Agreement) and Kyoto (Kyoto Protocol) is a tough balancing act as Malaysia's carbon dioxide emissions' keep increasing each year, and the trend in the past few decades is upsetting.

Since accounting is important for corporations in business management, accountants can help concerned organizations to deal with organizational $\mathrm{CO}_{2}$ emissions by engaging to the carbon accounting. As measuring, recording, and communicating are the focal accounting principle, carbon accounting refers to a procedure that facilitates entity's direct or indirect carbon emissions measuring and monitoring that will eventually motivate better financial and non-financial performance. In consequence, as carbon accounting deals with professional responsibilities, accountants play an important role in carbon accounting establishment and implementation. Organizations must take prompt action to help reduce greenhouse gas emissions because $\mathrm{CO}_{2}$ emissions mitigation is a huge task that requires widely synchronized resolutions. Also, the overall discussions on this field and the results from prior studies remained inconclusive for developed and developing countries, particularly Malaysia. Sustainability efforts are considered costly, complex, and subjective to measure (Kasbun et al., 2016). This perception causes corporate organizations to be skeptical of sustainability efforts. Besides, it is considerably difficult for companies to instantly transform and adapt to a new sustainability norm in their business activities by integrating proper strategies focusing on carbon emissions. Companies are still reluctant to invest in sustainability strategy or carbon emissions reduction efforts and are unclear about the significance of carbon accounting implementation in their organizations. In Malaysia, the government holds a critical, authoritative role that can enforce carbon emissions mitigation and encourage industries' carbon reduction efforts. Despite the complexity of committing to sustainability efforts and relatively low climate change awareness, the carbon mitigation efforts are gaining momentum in Malaysia. In a study by Bakar et al. (2017), based on their survey, $80 \%$ of the organizations studied are probably concerned more about the negative or positive impacts of carbon emissions on the environment.

Despite that, companies and managers are stereotypically skeptical whether the public and stakeholders are seriously interested in their environmental and social performance, due to lack of information system, and they believe that the environmental performance costs outweigh its benefits (Solomon \& Lewis, 2002). According to a study by Downie and Stubbs (2012), although industrial participants are concerned with social and environmental matters, because of weak stakeholders' pressure on sustainability issues, companies and their managers tend to see sustainability efforts as unnecessary and irrelevant. In a way, the lack of stakeholders' pressure also demotivated them to do any changes in facilitating the efforts. This circumstance is parallel to the report by PwC (2013), the analysis on the reasons for Malaysian companies to stop reporting performance on climate change (such as corporate carbon performance) revealed that $44 \%$ are not disclosing GHGs emissions, $26 \%$ are not measuring GHGs emissions because it is voluntary, while $18 \%$ feel their stakeholders are not interested in their GHG emissions. The consequences were that most companies have no immediate motivation to change either their company strategy or use a carbon accounting system. Most companies have no immediate motivation to transform any of their company strategies because of low stakeholders' pressure, low firm governance supports, the 
INTERNATIONAL JOURNAL OF ACADEMIC RESEARCH IN ACCOUNTING, FINANCE AND MANAGEMENT SCIENCES

Vol. 11, No. 1, 2021, E-ISSN: 2225-8329 ๔ 2021 HRMARS

discovery that managers view sustainability reports as unnecessary and irrelevant and the perception that there will be many unnecessary preparations of documents to cater for carbon accounting implementation and disclosure of carbon performance.

However, carbon accounting is somehow needed and benefitted in various aspects for organizations. Carbon accounting provides systematic tools to quantify carbon emissions and help organizations make informed-decisions regarding mitigation strategies. The carbon information generated from carbon accounting could help improve companies' carbon reduction. If provided with the right guidance, carbon accounting can basically help recognize and classify which business activities or parts consume much energy, which is the starting point to help reduce the energy and resources used and improve organizations economically. This aspect signifies how carbon accounting assists organizations to attain a better carbon performance and also proves that carbon accounting does improve carbon emissions reduction (Alrazi \& Husin, 2016). Through carbon accounting, organizations operational cost that once accommodated for carbon emissions treatment could be lowered. Once a cost is lowered, better pricing can be set without affecting the margin to attract customers. If the number of customers grows, financial performance will point toward better results. In terms of social and business development, the use of carbon accounting can help attract the right employees, customers, and investors who strongly support green business and believe in growing together, environmentally, and financially. Ong et al. (2019) posits that stakeholders today presume organizations to take supplementary responsibility in its corporate decisions and actions which includes taking responsibilities over companies' own operational impact towards the environment, social and economic. Specifically, companies are expected to take full responsibilities over its manufacturing processes' damages towards the environment (Ong, Ng, Teh, Kasbun \& Kwan, 2019). Further, in terms of environment, carbon accounting implementation helps organizations become more environmentally conscious by taking carbon emissions and mitigation efforts into their accounts. This move fundamentally to create a real change that contributes to the achievement of Sustainable Development Goals (SDGs).

The proactive-ness of corporations in carbon emissions mitigation effort in Malaysia is on voluntary basis. Despite being on a voluntary basis, the developments of carbon strategy and carbon accounting have become critical in the current business sphere before the unforeseen threats arise in the future. Therefore, as the $\mathrm{CO}_{2}$ emissions issue is gaining worldwide attention, Malaysia's involvement is not an exception. One way to aid environmental improvement in dealing with climate change issues and achieve sustainability in Malaysia is via carbon emissions mitigation to reduce carbon footprint. Thus, to address the research problem, this research question was raised; does corporate carbon stakeholder collaboration positively influence the implementation of carbon accounting? Aligned with the research question, hence this study aim to investigate the relationship between corporate carbon stakeholder collaboration and the implementation of carbon accounting of companies certified with ISO 14001 within Malaysia.

\section{Literature Review}

\section{Carbon Accounting}

In this study, carbon accounting is referred as an accounting methods system that includes collect, record and analyzes corporate carbon emissions; where the carbon emissions information to be 
INTERNATIONAL JOURNAL OF ACADEMIC RESEARCH IN ACCOUNTING, FINANCE AND MANAGEMENT SCIENCES

Vol. 11, No. 1, 2021, E-ISSN: 2225-8329 @ 2021 HRMARS

accounted and reported for internal and external decision-making process concerning carbon emissions reduction and profitability associated. Carbon accounting is fundamentally a new conception that has emerged in the accounting literature for the last few years. In the matter of climate change and environmental deterioration caused by businesses, many aspects of accounting should be considered to face the challenges. The consideration should include not only the environmental aspects but social and economic aspects as well. Carbon accounting has emerged as a field of interest to both academicians and practitioners. Carbon accounting varies differently from various perspectives, and the definition of carbon accounting varies across various disciplines. Other than its differences between socioeconomic and scientific approaches, it is essentially beneficial to investigate the incoherence between diverse frameworks of carbon accounting in different governance perspectives (Ascui \& Lovell, 2011). Stechemesser and Guenther (2012) suggested that the definition of carbon accounting proposed by Ascui and Lovell (2011) can be used to operationalize research questions by academics, restrict obligatory and voluntary accounting by legislators, and establish carbon accounting in companies by practitioners. Ascui and Lovell (2011) defined a comprehensive operational definition of carbon accounting where carbon accounting includes the estimation, calculation, measurement, monitoring, reporting, validation, verification, and auditing; of carbon dioxide $\left(\mathrm{CO}_{2}\right)$, carbon dioxide equivalents $\left(\mathrm{CO}_{2} \mathrm{e}\right)$, or any kind of greenhouse gases; emissions to the atmosphere, removals from the atmosphere, emission rights, emission obligations, emission reductions, legal or financial instruments linked to the these trades or transactions of any of the mentioned, impacts on climate change or impacts from climate change; at either global national, sub-national, regional civic, organizational, corporate, project, installation, event, product, or supply chain level; for mandatory or voluntary (levels mentioned) purposes. Kolk, Levy, and Pinkse (2008) defined carbon accounting as -The instrument to calculate $\mathrm{CO}_{2}$ quantum either emitted or sequestered in a biomass sink is carbon accounting.

Carbon accounting tools and the rationality of its outcome are both considered complex and cause organizations to forget about nature (Gibassier, Michelon \& Cartel, 2020). However, these new forms of accounting, particularly like carbon accounting, are probably a significant facet to the world that is sensible about environmental constraints and issues and significant in achieving harmonious connections between human beings with the natural world surroundings (Hopwood, 2009). Carbon accounting in which sustainable development plays a vital role in obliging the expansion of economically-oriented short term accounting practices is to be instilled not solely by direct impacts and interactions of corporations but also in the society and environment in which the organization operates in. Carbon accounting can be forthrightly seen as an extreme non-financial performance measurement system with overall quantification that includes behavioral inquiries and consequences (Hartmann, Perego \& Young, 2013). A principal challenge for the formation and introduction of a corporate carbon accounting is the development of a system that can attend various needs of overall functions efficiently. The corporate carbon reduction visions embed is needed such as, policies, strategies, indicators, timetables and documentation methods to observe improvements. These visions can be attained by installing company's carbon information management system(s) that evolves with its financial accounting procedures (Schaltegger \& Csutora, 2012). Initiating carbon accounting is allegedly to produce more benefits such as save costs, improve the company's competitiveness, and accomplish internal coordination (Rankin, Windsor \& Wahyuni, 2011; Ratnatunga \& Jones, 2012). The environmental strategy influences the usage of environmental 
INTERNATIONAL JOURNAL OF ACADEMIC RESEARCH IN ACCOUNTING, FINANCE AND MANAGEMENT SCIENCES

Vol. 11, No. 1, 2021, E-ISSN: 2225-8329 @ 2021 HRMARS

performance, which is measured directly and indirectly through the effects of system and metricrelated characteristics (Perego \& Hartmann, 2009). In their earlier study, Perego and Hartmann (2005) observed that the relationship between environmental strategy and environmental performance measurement systems operationalization is somehow interceded by the environmental management accounting systems facades such as the sophistication and properties of the measurement systems. Where the environmental management accounting provides information to be used by the corporate management to assess opportunities for economic and environmental improvement, and environmental strategy implementation facilitates the emergence of adoption of environmental management system by companies (Ong, Teh, Selley \& Magsi, 2018). There is a close interplay between a strategy; the carbon stakeholder collaboration and carbon accounting (system) that makes them interdependent. This is also corresponding to Luo and Tang (2016) where they posit that a carbon accounting system is a method to materialize a company's carbon stakeholder collaboration in order to increase efficiency in mitigating carbon emissions and gain a competitive advantage.

\section{Carbon Stakeholder Collaborations}

Freeman (1984) defined a stakeholder is as "any group or individual who can affect or is affected by the achievement of the companies' objectives," and according to Roberts (1992), a stakeholder can include stockholders or shareholders, creditors, public interest groups, and governmental bodies. As external stakeholder groups can have positions that could diverge from or are adversarial to a corporation's agenda, especially regarding social responsibility issues, organizations may need to respond to the concerns of the stakeholder groups, and one of the crucial ways they can do this is through the use of social responsibility or sustainability disclosure (Roberts, 1992). Sustainability grounds on the progress of a global framework of which an endless satisfaction of human needs constitutes the ultimate goal (Brundtland, 1987); at the organizational level, corporate sustainability can accordingly be defined as meeting the needs of a company's direct and indirect stakeholders and at the same time without compromising its ability to meet the future stakeholders' needs. In succeeding this goal and supporting the concern on accounting for carbon and adapting behavior toward this goal, organizations must have to maintain and grow their economic, social, and environmental capital base while contributing vigorously to sustainability within the political domain (Dyllick \& Hockerts, 2002). Rawhouser, Cummings and Marcus (2017) posit that stakeholders are increasingly concern about firms' sustainability efforts and are extensively believed to have interests in associations of the public's good and long-term sustainability. Current massive carbon emissions is one of the global sustainability issues, when a range of stakeholders started to pay attention to the potentially very serious consequences, there is the need for organizations to take a serious emergency action (Renukappa, Akintoye, Egbu \& Goulding, 2013). There are groups of potential stakeholders that may collaborate with companies in carbon reduction activities; these stakeholders consider the credibility and influence of carbon accounting. Due to the environmental threat caused by $\mathrm{CO}_{2}$ emissions, at the corporate level, such as public companies, business associations, and nongovernmental organizations (NGOs) monitor their carbon emissions, prepare emission reduction reports, and assess climate risk through internal management accounting and control systems. Whereas besides investors and stakeholders that are generally informed and have a growing interest in environmental issues, Malaysian consumers are also increasingly concerned about the environmental impacts of the products and services they purchased (UNDP Malaysia, 2016). 
Accounting literature has deliberated the impact of external pressure on companies' strategies. Management has also acknowledged that stakeholders' pressure is a crucial influencer in the implementation of internal strategies and the management control choice (Alrazi, Villiers, \& Staden, 2015). As Dyllick and Hockerts (2002) observed, one of the objectives is to bring stakeholders into the subject matter so that interventions at the corporate level brings in the focused awareness and pay more attention to their present and future needs. Deegan (2002) also posits that the relationship between stakeholder pressure and the environmental performance of organizations exists because organizations operate within a social framework of norms and values. Accounting is responsible for generating numbers and narratives to assist in testing the credibility of carbon reduction; it is also responsible for managing the environment that requires stakeholders to collaborate and choose proper incentives to transform accordingly. According to Luo \& Tang (2014), the carbon mitigation initiatives in lieu of climate change efforts that have been recommended and implemented by large business organizations have provided many visions for accounting professionals to apply their human capital and engage in GHGs mitigation. There is a need for strategic policy development and sustainability execution when there is a paradigm shift in the economy. Critical skills related to carbon accounting that has emerged within the carbon-sensitive industries must be fully utilized to offset their carbon liabilities. Moreover, because of that, the knowledge of accounting-based climate is valuable in the industry. It is critical for researchers and academics to develop understanding concerning carbon management and carbon accounting to prepare future accountants to be attentive of and understand the context of carbon accounting (Tang \& Luo, 2014). In the matter of $\mathrm{CO}_{2}$ emissions, the pressure from the stakeholders, which includes the government, investors, employees, NGOs, the media, etc. can increase; align with the increase of pressure, a potentially high cost could increase as well. This will cause an environmental catastrophe, and therefore, many corporations are considering implementing green accounting (Spencer, Adams, \& Yapa, 2013). Stakeholders' engagement and activities may not be directly related to a company's business implementation in cooperation with private or public actors (Damert, Paul, \& Baumgartner, 2017). Therefore companies may collaborate with trade associations such as the World Business Council on Sustainable Development (WBCSD), political actors such as UN Global compact and nongovernmental organizations to develop voluntary emission reduction targets, codes of conduct or business ethics (Eberlein \& Matten, 2009; Sullivan, 2010). Another form of stakeholder engagement is corporate citizenship activities, such as academic scholarship provision, tree-planting projects, or public education events (Jeswani, Wehrmeyer \& Mulugetta, 2008; Kolk et al., 2008).

This study supports the implementation of strategic intent towards carbon reduction and carbon emissions visibility through stakeholders' engagement. Through stakeholder collaboration it helps companies develop strategies for dealing with the carbon-related issues. Later, via accounting, the carbon information system can help capture a company's conduct and help in reduce carbon trajectories. The national greenhouse reduction is a program that requires collaborations between government, corporations, and other stakeholders. Due to the collaborative nature, trust is a crucial characteristic of the relationships between parties involved. Through this collaborative trust, organizations are hoping for rational stakeholders to make an active decision on whom to trust or be trusted by those that they are collaborating with. Based on these conditions, this study considers carbon stakeholder collaboration as another dimension of carbon strategies; this collaborative 
INTERNATIONAL JOURNAL OF ACADEMIC RESEARCH IN ACCOUNTING, FINANCE AND MANAGEMENT SCIENCES

Vol. 11, No. 1, 2021, E-ISSN: 2225-8329 ๑ 2021 HRMARS

venture is expected to evaluate the presented carbon information, and further to make proper decisions for organizations. Without stakeholder engagements, companies will probably stop reporting on carbon because they feel their stakeholders are not interested in their GHG emissions (PwC, 2013). The demand to consider $\mathrm{CO}_{2}$ emissions, which is a universal sustainability issue, had increased since the early twenty-first century, especially when stakeholders began to focus on the potentially serious unforeseen consequences. In this light, stakeholder collaboration will affect the implementation of carbon accounting which later leads to better economic and environmental performances of organizations.

\section{Hypotheses Development}

The resource-based theory is an important idea in strategy as it suggests the potential to explain sustained competitive advantage, which is the process of delivering long-run abnormal returns to shareholders (Toms, 2010). Such returns can be conveyed through accessing resources, including, for example, monopoly control by having a competitive heterogeneity (example: organization's own carbon strategy), or the creation of difficult to replicate resources as in the resource-based theory. Resource-based theory appears to be an important concept in strategic management area. The theory of resource-based behavior proposes that organizations derive their competitive advantage through the proactive use of its resources (Barney, 1991). The relationship concerning a company's distinctive capacities and its performance commonly found in some classic management studies. For example, the notions related to resource-based theory, such as the companies' distinctive competence, the strategy structure, and an internal assessment of strengths and weaknesses, led to the recognition of distinctive competencies (Wernerfelt, 1984). The resource-based theory grew as significance to the structure-conduct-performance paradigm in the view of organizational view (Porter \& Kramer, 2006). It has become a prominent management theory that companies can use to analyze resources as potential foundations of competitive advantage. A potential way to create a strategy is by developing the internal capabilities first and applying them by aligning with the external environment. Thus, in order to gain resource value, a company must consider and access risks and opportunities in their surrounding environment. The competitive advantage is identified by these competencies or capabilities and management abilities to produce greater performance (Barney, 1991). The resource-based theory can be operationalized based on the understanding that resources are separated into tangible, intangible, and personnel-based (Grant, Tobergte \& Curtis, 2013). Wernerfelt (1984) suggests that analyzing an organization from its resources can lead to insights into their differences from the traditional perspective. The study also defines resources as both tangible and intangible assets (example; like company's brand names or employment of skilled personnel) that are secured semi-permanently to an organization and examined the associations between resources and profitability in terms of the barriers of resource position (for example; the resources difficult for others to cope up with or to duplicate).

The focal point in the deliberation on sustainability in corporations is the inclusion of stakeholders and the integration of their respective demands. The nature and extent of engagement by stakeholders are influenced by the need to access requisite knowledge, and the system's need to be perceived as legitimate (Gilbert et al., 2011). Three standard features motivate organizations to find cross-sectionals partners (Huxham \& Vangen, 1996), there are, firstly, a collaboration that helps an organization achieve something impossible to accomplish. Secondly, collaboration helps 
INTERNATIONAL JOURNAL OF ACADEMIC RESEARCH IN ACCOUNTING, FINANCE AND MANAGEMENT SCIENCES

Vol. 11, No. 1, 2021, E-ISSN: 2225-8329 @ 2021 HRMARS

organizations to confront social or macro-environmental problems that are impossible to solve on their own, for example, the important reason for social partnerships. Thirdly, organizations may gain an adaptive advantage through collaboration. The collaborations of stakeholders prepare organizations to adaptively respond to environmental complexity, uncertainty, or turbulence. Organizations nowadays are also expected by their stakeholders to contribute to society and significantly involve more in sustainability activities (for example, active in carbon emissions reduction) (Joshi \& $\mathrm{Li}, 2016$ ). In this consensus, individuals, organizations, and stakeholders that have a mutual interest in a specific social or environmental problem can cooperatively work together to improve ways to measure progress toward their shared goals. In line with the prepositions of resource-based theory, therefore, the following hypothesis is proposed:

$\mathrm{H} 1$ : Carbon stakeholder collaboration positively influences the implementation of carbon accounting.

\section{Methodology}

This study is a quantitative research that is generally associated with positivism philosophy, primarily when predetermined and high structured single data collection techniques are used. Based on the research questions, the research purpose of this study is descriptive, which is to gain an accurate profile of events, persons, or situations. Research strategy of this study is by using a questionnaire survey that is related to the deductive research approach. The questionnaire is prominent as it consents the standardized data collection from a sizeable population in a highly economical way, allowing easy comparison. The time horizon is the cross-sectional study involving the study of a particular phenomenon at a particular time (Saunders, Lewis \& Thornhill, 2016). This study sought to evaluate how ISO 14001 certified Malaysian companies proactively react to have carbon strategies adaptation and implement carbon accounting. Thus this study's population comprises of Malaysian organizations with the International Organization for Standardization, ISO 14001 Environmental Management System Certification granted by SIRIM, the Standard and Industrial Research Institute of Malaysia. These organizations certified with ISO 14001 EMS reflect higher environmental proactivity for this study and are expected to implement considerable numbers of environmental strategies. ISO 14001 certification is also expected as the indication that companies integrate environmental values into their business operations and reduce liabilities (Ahmed, Nusari \& Zaroog, 2012) because ISO 14001 does not only serve as a mere standard, it contributes to the company's success by assisting the system established to protect the environment and reduce costs in a long period (Ong et al., 2015). The sampling method is by using census sampling from the population considering the entire population. The questionnaire items for this study are adapted from previous related literature. Some modifications had been made for adequate content meanings and to accommodate the research objectives of this study. Most of the questionnaire items are based on the respondents' perceptions of their respective companies. The perceptual measures are more considerable than objective measures in this research due to the limited accessibility to companies' carbon information and transparency. Perceptual data from managers also tend to associate strongly with company data from secondary sources (Singh, Darwish \& Potocnik, 2016). The respondents in this study would be those inclined with sustainability or environmental knowledge of their organizations, such as the general manager, operations manager, financial manager, senior manager, and environmental manager. Data collected were then analyzed using partial least square-structural equation modeling (PLS-SEM) for inferential analysis of data. All PLS-SEM analyses executed using the Smart PLS 3.2.7. The choice of PLS-SEM utilization was based on several considerations related to the 
INTERNATIONAL JOURNAL OF ACADEMIC RESEARCH IN ACCOUNTING, FINANCE AND

MANAGEMENT SCIENCES

Vol. 11, No. 1, 2021, E-ISSN: 2225-8329 @ 2021 HRMARS

research context; especially due to the small sample sizes of management accounting's characteristics; PLS-SEM could cater to this small sample size (Nitzl, 2016).

\section{Results and Discussion}

Response rate of this study presents the total of 136 valid survey questionnaires that were used for data analysis. Table 1 presents the demographic profiles; the frequency distributions of the companies. The frequency distribution indicates that the majority of sample companies are aged between 21 to 40 years ( $n=92,67.7 \%$ ) which is considered as long-established companies; followed by companies that have been established for over 40 years $(n=24,17.6 \%)$ and the remaining are below 20 years of age $(n=20,14.7 \%)$. The companies' total number of full-time employees indicates the size of the sample companies, where the majority is of the small and medium-sized companies that employ less than 200 full-time employees ( $n=69,50.7 \%)$; followed by huge-sized companies employing more than 500 full-time employees $(n=36,26.5 \%)$. The remaining companies are largesized companies with a workforce between 200 to 500 employees ( $n=31,22.8 \%$ ). These sample companies are from different industrial sectors with the majority is from the industrial products sector ( $n=34,25 \%)$; followed by other sectors $(n=31,22.8 \%)$ that the respondents stated, which include engineering, technology, transportation and automotive, finance, manufacturing, infrastructure, commercial, materials, consulting, operation and maintenance, authority, and government agencies. Followed by construction $(n=21,15.4 \%)$, consumer products $(n=20,14.7 \%)$, oil and gas $(n=11,8.1 \%)$, plantation $(n=5,3.7 \%)$, trade and services and chemical sectors with the same frequency $(n=3,2.2 \%)$, while the remaining are of the same frequency include mining, properties, education and healthcare sectors $(n=2,1.5 \%)$. In terms of ownership, majority of the sample companies' ownership is local ownership ( $n=94,69.1 \%)$, followed by a joint venture of local and foreign ownership ( $n=36,26.5 \%)$ and the remaining is foreign ownership $(n=6,4.4 \%)$. 
INTERNATIONAL JOURNAL OF ACADEMIC RESEARCH IN ACCOUNTING, FINANCE AND MANAGEMENT SCIENCES

Vol. 11, No. 1, 2021, E-ISSN: 2225-8329 @ 2021 HRMARS

Table 1: Demographic profile $(n=136)$

\begin{tabular}{|c|c|c|}
\hline Description & Frequency & Percentage (\%) \\
\hline \multicolumn{3}{|l|}{ Company's age } \\
\hline Below 20 years & 20 & $14.7 \%$ \\
\hline Between 21 to 40 years & 92 & $67.7 \%$ \\
\hline Over 40 years & 24 & $17.6 \%$ \\
\hline \multicolumn{3}{|l|}{ Company's number of employees } \\
\hline Below 200 (small and medium-size) & 69 & $50.7 \%$ \\
\hline 200 to 500 (large size) & 31 & $22.8 \%$ \\
\hline Over 500 (larger) & 36 & $26.5 \%$ \\
\hline \multicolumn{3}{|l|}{ Companies' industrial sector } \\
\hline Consumer products & 20 & $14.7 \%$ \\
\hline Industrial products & 34 & $25 \%$ \\
\hline Construction & 21 & $15.4 \%$ \\
\hline Trade and services & 3 & $2.2 \%$ \\
\hline Oil and gas & 11 & $8.1 \%$ \\
\hline Plantation & 5 & $3.7 \%$ \\
\hline Mining & 2 & $1.5 \%$ \\
\hline Properties & 2 & $1.5 \%$ \\
\hline Chemicals & 3 & $2.2 \%$ \\
\hline Education & 2 & $1.5 \%$ \\
\hline Healthcare & 2 & $1.5 \%$ \\
\hline Others & 31 & $22.8 \%$ \\
\hline \multicolumn{3}{|l|}{ Types of ownership } \\
\hline Local & 94 & $69.1 \%$ \\
\hline Foreign & 6 & $4.4 \%$ \\
\hline Joint venture local and foreign & 36 & $26.5 \%$ \\
\hline
\end{tabular}

\section{Carbon Stakeholder Collaboration and Carbon Accounting}

Table 2 presents the hypothesis testing result of the direct effect; on carbon stakeholder collaboration and carbon accounting implementation. The procedure of bootstrapping executed via PLS-SEM given the statistical objective to show the significance of the structural model relationships. Bootstrapping is a non-parametric approach for assessing the path coefficient precision, and the procedure produces standard error and t-values in investigating the statistical significance of the path coefficients (Hair, Ringle \& Sarstedt, 2011). The beta $\beta$ value, usually in the range between 0.20 and 0.30 are considered significant. The empirical t-value needs to be significant at a certain confidence level (P-value) to confirm the hypothesized relationship (Hair et al., 2014), or it may be otherwise. Parameters with the presence of $t$-value greater than 1.96 indicate $95 \%$ confidence level $(p<0.05)$ (Hair et al., 2014). Table 2 shows the results of the significance of the direct path. 
INTERNATIONAL JOURNAL OF ACADEMIC RESEARCH IN ACCOUNTING, FINANCE AND MANAGEMENT SCIENCES

Vol. 11, No. 1, 2021, E-ISSN: 2225-8329 @ 2021 HRMARS

Table 2: Direct paths coefficients results

\begin{tabular}{|c|c|c|c|c|c|c|}
\hline $\begin{array}{c}\text { Hypo- } \\
\text { theses }\end{array}$ & Paths & $\begin{array}{c}\text { Standard } \\
\text { beta }(\boldsymbol{\beta})\end{array}$ & $\begin{array}{c}\text { Standard } \\
\text { error }(\sigma \overline{\mathbf{x}})\end{array}$ & t-value & p-value & Results \\
\hline H1 & CSC > CA & 0.307 & 0.114 & $2.689 * *$ & 0.007 & Significant \\
\hline
\end{tabular}

Notes: ${ }^{* *}$ significant at $\mathrm{p}<0.01$ (two-tailed test)

The result of the direct path between carbon stakeholder collaboration and carbon accounting (CSC $>C A)$ shows that carbon stakeholder collaboration has a significant positive effect on carbon accounting (standardized $\beta=0.307, \mathrm{p}<0.01$ ). $\mathrm{H} 1$ is supported. Stakeholders such as customer or consumer, suppliers, communities (NGOs and the public) are increasingly concern about business' sustainability efforts, besides that, stakeholders from the government or non-profit sectors are extensively believed to have interests that are better aligned with the public's good and long-term sustainability (Rawhouser, Cummings, \& Marcus, 2017). The findings in this study show that carbon stakeholders' collaboration indeed influences the implementation of a carbon accounting system in a company. According to a study by Johnsso et al (2010), there is a certainty that the available technologies at present contribute to the achievement of significant reductions in $\mathrm{CO}_{2}$ emissions. Hence stakeholders grasp a strong opinion that technologies and measures should be the preferred choice in converting the energy system. This is consistent with the prediction of this study that stakeholders' collaboration will influence the implementation of carbon accounting, even though most stakeholders consider it as difficult or complicated to significantly cut $\mathrm{CO}_{2}$ emissions through the currently available approaches (Johnsson et al., 2010). One of the potential reasons is that, centered on the findings, the communication on the complexity of $\mathrm{CO}_{2}$ issues depend on the information provided through the collaboration with stakeholders. The $\mathrm{CO}_{2}$ opinion and information from the stakeholder collaboration provide useful insights for companies to implement their carbon accounting because these stakeholders are knowledgeable in the current carbon development. Since these stakeholders, such as suppliers and communities, are the parties directly involved in carbon development, their information is reliable to be incorporated in the companies' carbon accounting. However, the collaboration between companies and stakeholders need to mutually empathetic, companies need to provide transparent $\mathrm{CO}_{2}$ reports to stakeholders, and stakeholders should provide reliable opinions and positive pressures in return. It may also, for different stakeholders to reach an agreement with companies regarding collaborations on carbon matters, however, one of the challenges is the possibility of unwillingness to provide information on collaborations if companies' perceived high-quality information is not as expected by the stakeholders and vice versa, which therefore might harm their reputations if the high quality of perceived information from companies is not achievable (Mors, Weenig, Ellemers \& Daamen, 2010). Table 3 presents the direct effects path coefficients assessment with the alignment of the path, hypothesis statement and the results' assessment. The effect size $\left(f^{2}\right)$ of 0.088 indicates the small threshold value of the measure of the impact of the exogenous construct (carbon stakeholder collaboration) on the endogenous construct (carbon accounting). 
INTERNATIONAL JOURNAL OF ACADEMIC RESEARCH IN ACCOUNTING, FINANCE AND MANAGEMENT SCIENCES

Vol. 11, No. 1, 2021, E-ISSN: 2225-8329 @ 2021 HRMARS

Table 3: Direct effects path coefficients assessment

\begin{tabular}{|l|l|l|l|}
\hline $\begin{array}{c}\text { Hypo- } \\
\text { thesis }\end{array}$ & \multicolumn{1}{|c|}{ Paths } & \multicolumn{1}{|c|}{ Hypotheses statement } & \multicolumn{1}{c|}{ Assessment } \\
\hline $\mathrm{H} 1$ & $\begin{array}{l}\text { Carbon stakeholder } \\
\text { collaboration }>\text { carbon } \\
\text { accounting }\end{array}$ & $\begin{array}{l}\text { Carbon stakeholder } \\
\text { collaboration positively } \\
\text { influences the implementation } \\
\text { of carbon accounting. }\end{array}$ & $\begin{array}{l}\text { Significant } \\
\beta=0.307(p<0.01) \\
f^{2}=0.088\end{array}$ \\
\hline
\end{tabular}

Notes: $\beta=$ standard beta; $f^{2}=$ effect size

\section{Conclusion}

This study aim to investigate the relationship between corporate carbon stakeholder collaboration and the implementation of carbon accounting of companies certified with ISO 14001 within Malaysia. Based on the findings, carbon stakeholder collaboration is incorporated significantly with the implementation of carbon accounting. The findings proved that with the existence of carbon stakeholder collaboration as a strategy to reduce carbon emissions of an organization lead to the implementation of carbon accounting as a system to capture all useful carbon-related information for carbon emissions mitigation effort. Basically a simple form of carbon accounting is potentially accessible to all entities. That way, businesses are not discouraged by the time consumed to generate carbon accounts or by the complexity of the process. The simplest form of carbon accounting guidelines has already developed (for example, carbon accounting guidelines developed by ACCA and Green Accountancy in the United Kingdom). It involves decisions that primarily start from narrowing down the reporting scope by focusing on business activities that significantly involve emissions. The guidelines provide reporting form, methodology, and even conversion factors (for example, energy used converted into emissions in metric tons) to encourage more organizations to protect the environment, gain business growth, and save cost.

Theoretically, the findings of this study contribute to the extent of carbon accounting literature, particularly in Malaysia. The literature of carbon accounting is not generally scarce worldwide (Afionis, Sakai, Scott, Barrett \& Gouldson, 2017; Chakrabarty \& Wang, 2013), but the literature is empirically scarce in Malaysia. The results of this study respectively show a positive analytical role of corporate carbon stakeholder collaboration to influence the implementation of carbon accounting. Further this study contextually contributes to providing new insights into carbon accounting in Malaysia specifically in the accounting perspective by discussing carbon accounting at the firm level, increase awareness, and contributes to a better fundamental understanding of carbon accounting in accounting perspective, especially in spreading awareness and encouraging companies that particularly considering carbon management systems and accounting in concerns to the environment.

This knowledge and the basics of carbon accounting in Malaysia are vital for developing new corporate carbon strategies, policies, guidelines, and initiatives. Therefore, it is impactful not only to the managers of organizations but also the stakeholders, regulators, policymakers, government, etc. 
INTERNATIONAL JOURNAL OF ACADEMIC RESEARCH IN ACCOUNTING, FINANCE AND MANAGEMENT SCIENCES

Vol. 11, No. 1, 2021, E-ISSN: 2225-8329 ๔ 2021 HRMARS

Since empirical research on accounting issues concerning carbon emissions in Malaysia is scarce, this study addressed carbon accounting that actually related to many organizations various $\mathrm{GHGs}$ or $\mathrm{CO}_{2}$ contexts. Thus by specifying the most problematic carbon accounting issues and utilizing the accounting standard-setters such as the Malaysian Accounting Standards Board (MASB), the piece of evidence posits in this study might provide awareness and tangible solutions in dealing with the complexities related to corporate carbon emissions and accounting in Malaysia. Future studies could work on various data that possibly generated from different sources, for example organizations that are possibly more environmentally proactive and intensely mitigating $\mathrm{CO}_{2}$ could be taken into consideration aside from companies certified with ISO 14001. Organizations that are carbon-intense and have a high intensity of $\mathrm{CO}_{2}$ should also be included for investigation in future studies. Additionally, with all these characters and certifications, this study could be extended to include other countries as a comparison-based study.

Carbon accounting knowledge is indeed significant in the current climate pandemonium. In this climate context, carbon accounting contributes to the proactive efforts to provide future sustainability. Presently, thousands of corporations around the world including Malaysia have joined alliances and initiatives designed to monitor their business practices and regulate them to more emissions-conscious ways. Gradually, organizations seek ways to increase profits without destroying the environment that makes them prosperous and sustainability possible. This study hopes to convey the awareness because without aggressive transformative action to reduce carbon and GHGs emissions, the world's temperature will continue escalating, exposing millions of people to drought, pushing people into extreme poverty, the emergence of a new pandemic, as well as deteriorating the Earth. For every fraction of a degree that temperatures increase, these problems will worsen. Even after decades, researchers and activists are struggling to find holistic solutions to climate change caused by GHGs, especially carbon emissions, and get the world leaders to take the climate threat seriously. Hopefully, actions are not going to be delayed anymore. It might be quite challenging for organizations, especially in Malaysia, to be sufficiently proactive in reducing carbon emissions. However, it is the crucial obligation that will define us in the eyes of future generations, whereby providing to that challenge may promise more healthy economy and environment with unprecedented greater opportunities to come.

\section{References}

Afionis, S., Sakai, M., Scott, K., Barrett, J., \& Gouldson, A. (2017). Consumption-based carbon accounting: does it have a future? Wiley Interdisciplinary Reviews: Climate Change, $8(1)$.

Ahmed, M. M., Nusari, M. S., \& Zaroog, O. S. (2012). Environmental management system in small and medium enterprises in Malaysia: a review. International Journal of Latest Technology in Engineering \& Management (IJLTEM), 1(23), 2456-1770.

Alrazi, B., Villiers, C. D., \& Staden, C. J. V. (2015). A comprehensive literature review on, and the construction of a framework for, environmental legitimacy, accountability and proactivity. Journal of Cleaner Production, 102, 44-57.

Alrazi, B., \& Husin, N. M. (2016). Institutional Governance Framework for Determining Carbon-related Accounting Practices: An Exploratory Study of Electricity Generating Companies in Malaysia. IOP Conference Series: Earth and Environmental Science, 32(1).

Ascui, F., \& Lovell, H. (2011). As frames collide: making sense of carbon accounting. Accounting, Auditing \& Accountability Journal, 24(8), 978-999. 
INTERNATIONAL JOURNAL OF ACADEMIC RESEARCH IN ACCOUNTING, FINANCE AND MANAGEMENT SCIENCES

Vol. 11, No. 1, 2021, E-ISSN: 2225-8329 @ 2021 HRMARS

Bakar, N. A., Abdullah, H., Ibrahim, F. W., \& Jali, M. R. M. (2017). Green economy: Evaluation of Malaysian company environmental sustainability. International Journal of Energy Economics and Policy, 7(2), 139-143. Retrieved from https://www.scopus.com/inward/record.uri?eid=2-s2.085017648231\&partnerID=40\&md5=7c9713dd6d545154d7f06dc2c128ea2f

Barney, J. B. (1991). Firm Resources and Sustained Competitive Advantage. Journal of Management, 17(1), 99-120. https://doi.org/10.1177/014920639101700108

Chakrabarty, S., \& Wang, L. (2013). Climate change mitigation and internationalization: The competitiveness of multinational corporations. Thunderbird International Business Review, 55(6), 673-688. https://doi.org/10.1002/tie.21583

Damert, M., Paul, A., \& Baumgartner, R. J. (2017). Exploring the determinants and long-term performance outcomes of corporate carbon strategies. Journal of Cleaner Production, 160, 123138. https://doi.org/10.1016/j.jclepro.2017.03.206

Downie, J., \& Stubbs, W. (2012). Corporate carbon strategies and greenhouse gas emission assessments: The implications of scope 3 emission factor selection. Business Strategy and the Environment, 21(6), 412-422. https://doi.org/10.1002/bse.1734

Gibassier, D., Michelon, G., \& Cartel, M. (2020). The future of carbon accounting research: "we've pissed mother nature off, big time". Sustainability Accounting, Management and Policy Journal, 11(3), 477-485. https://doi.org/10.1108/SAMPJ-02-2020-0028

Grant, R., Tobergte, D. R., \& Curtis, S. (2013). The resource-based theory of competitive advantage: Implications for strategy formulation. Journal of Chemical Information and Modeling, 53(9), 1689-1699. https://doi.org/10.1017/CB09781107415324.004

Hair, J., Hult, T., Ringle, C., \& Sarstedt, M. (2014). A Primer on Partial Least Squares Structural Equation Modeling (PLS-SEM). Thousand Oaks, CA: Sage Publications, Inc.

Hair, J. F., Ringle, C. M., \& Sarstedt, M. (2011). PLS-SEM: Indeed a Silver Bullet. Journal of Marketing Theory and Practice, 19(2), 139-151. https://doi.org/10.2753/MTP1069-6679190202

Hartmann, F., Perego, P., \& Young, A. (2013). Carbon accounting: Challenges for research in management control and performance measurement. Abacus, 49(4), 539-563. https://doi.org/10.1111/abac.12018

Hopwood, A. G. (2009). Accounting and the environment. Accounting, Organizations and Society, 34(3-4), 433-439. https://doi.org/10.1016/j.aos.2009.03.002

Huxham, C., \& Vangen, S. (1996). Working together Key themes in the management of relationships between public and non-profit organizations. International Journal of Public Sector Management, 9(7), 5-17.

Jeswani, H. K., Wehrmeyer, W., \& Mulugetta, Y. (2008). How Warm Is the Corporate Response to Climate Change? Evidence from Pakistan and the UK. Business Strategy and the Environment, 60, 46-60.

Johnsson, F., Reiner, D., Itaoka, K., \& Herzog, H. (2010). Stakeholder attitudes on Carbon Capture and Storage - An international comparison. International Journal of Greenhouse Gas Control, 4(2), 410-418. https://doi.org/10.1016/j.ijggc.2009.09.006

Joshi, S., \& Li, Y. (2016). What is corporate sustainability and how do firms practice it? A management accounting research perspective. Journal of Management Accounting Research, 28(2), 1-11.

Kasbun, N. F., Teh, B. H., \& Ong, T. S. (2016). Sustainability reporting and financial performance of Malaysian public listed companies. Institutions and Economies, 8(4).

Kolk, A., Levy, D., \& Pinkse, J. (2008). Corporate responses in an emerging climate regime: The 
INTERNATIONAL JOURNAL OF ACADEMIC RESEARCH IN ACCOUNTING, FINANCE AND

MANAGEMENT SCIENCES

Vol. 11, No. 1, 2021, E-ISSN: 2225-8329 @ 2021 HRMARS

institutionalization and commensuration of carbon disclosure. European Accounting Review, 17(4), 719-745. https://doi.org/10.1080/09638180802489121

Luo, L., \& Tang, Q. (2014). Carbon tax, corporate carbon profile and financial return. Pacific Accounting Review, 26(3), 351-373. https://doi.org/10.1108/PAR-09-2012-0046

Luo, L., \& Tang, Q. (2016). Determinants of the Quality of Corporate Carbon Management Systems: An International Study. International Journal of Accounting, 51(2), 275-305. https://doi.org/10.1016/j.intacc.2016.04.007

Mors, E. T., Weenig, M. W. H., Ellemers, N., \& Daamen, D. D. L. (2010). Effective communication about complex environmental issues: Perceived quality of information about carbon dioxide capture and storage (CCS) depends on stakeholder collaboration. Journal of Environmental Psychology, 30(4), 347-357. https://doi.org/10.1016/j.jenvp.2010.06.001

Nitzl, C. (2016). The use of partial least squares structural equation modelling (PLS-SEM) in management accounting research: Directions for future theory development. Journal of Accounting Literature, 37, 19-35. https://doi.org/10.1016/j.acclit.2016.09.003

Ong, T. S., Ng, Y. H., Teh, B. H., Kasbun, N. F., \& Kwan, J. H. (2019). The Relationship between Corporate Governance Attributes and Environmental Disclosure Quality of Malaysian Public Listed Companies. Asian Journal of Accounting and Governance, 12, 1-12.

Ong, T. S., Teh, B. H., Selley, S., \& Magsi, H. (2018). The Relationship between Contingent Factors that Influence the Environmental Management Accounting and Environmental Performance among Manufacturing Companies in Klang Valley, Malaysia. International Journal of Economics and Management, 12(April), 205-232.

Ong, T. S., Teh, B. H, Goh, H. H., \& Thai, S. B. (2015). ISO 14001 Certification and Financial Performance of Companies. Asia Pacific Management Accounting Journal, 10(2), 58-77.

Perego, P., \& Hartmann, F. (2009). Aligning Performance Measurement Systems With Strategy : The Case of Environmental Strategy, 45(4), 397-428. https://doi.org/10.1111/j.14676281.2009 .00297$.

Porter, M. E., \& Kramer, M. R. (2006). Strategy \& Society: The link between competitive advantage and corporate social responsibility. Harvard Business Review, (December), 1-14.

PwC. (2013). Pulse check on climate change Insights from the ASEAN-5 countries. Price Water Cooper, (July).

Rankin, M., Windsor, C., \& Wahyuni, D. (2011). An investigation of voluntary corporate greenhouse gas emissions reporting in a market governance system. Accounting, Auditing \& Accountability Journal, 24(8), 1037-1070. https://doi.org/10.1108/09513571111184751

Rawhouser, H., Cummings, M. E., \& Marcus, A. (2017). Sustainability Standards and Stakeholder Engagement: Lessons From Carbon Markets. Organization \& Environment, (Special Issue: Creating Value for Stakeholders), 1-20. https://doi.org/10.1177/1086026617718434

Renukappa, S., Akintoye, A., Egbu, C., \& Goulding, J. (2013). Carbon emission reduction strategies in the UK industrial sectors: an empirical study. International Journal of Climate Change Strategies and Management, 5(3), 304-323. https://doi.org/10.1108/IJCCSM-02-2012-0010

Safaai, N. S. M., Noor, Z. Z., Hashim, H., Ujang, Z., \& Talib, J. (2011). Projection of $\mathrm{CO}_{2}$ Emissions in Malaysia. Environmental Progress \& Sustainable Energy, 30(4), 658-665. https://doi.org/10.1002/ep

Schaltegger, S., \& Csutora, M. (2012). Carbon accounting for sustainability and management. Status quo and challenges. Journal of Cleaner Production, 36, 1-16. 
INTERNATIONAL JOURNAL OF ACADEMIC RESEARCH IN ACCOUNTING, FINANCE AND

\section{MANAGEMENT SCIENCES}

Vol. 11, No. 1, 2021, E-ISSN: 2225-8329 (c) 2021 HRMARS

https://doi.org/10.1016/j.jclepro.2012.06.024

Singh, S., Darwish, T. K., \& Potocnik, K. (2016). Measuring Organizational Performance: A Case for Subjective Measures. British Journal of Management, 27, 214-224. https://doi.org/10.1111/1467-8551.12126

Solomon, A., \& Lewis, L. (2002). Incentives and Disincentives for Corporate Environmental Disclosure. Business Strategy and the Environment, 169(11), 154-169.

Spencer, S. Y., Adams, C., \& Yapa, P. W. S. (2013). The mediating effects of the adoption of an environmental information system on top management's commitment and environmental performance. Sustainability Accounting, Management and Policy Journal, 4(1), 75-102. https://doi.org/10.1108/SAMPJ-10-2011-0030

Stechemesser, K., \& Guenther, E. (2012). Carbon accounting: A systematic literature review. Journal of Cleaner Production, 36, 17-38. https://doi.org/10.1016/j.jclepro.2012.02.021

Toms, S. (2010). Value, Profit and Risk: Accounting and The Resource-Based View of the Firm. Accounting, Auditing \& Accountability Journal, 23(5), 647-670. https://doi.org/10.1108/09513571011054927

Wernerfelt, B. (1984). A Resource-based View of the Firm, 5(June 1982), 171-180. 